\title{
Clay Minerals at the Paleocene-Eocene Thermal Maximum: Interpretations, Limits, and Perspectives
}

\author{
Fabio Tateo \\ Istituto di Geoscienze e Georisorse, Consiglio Nazionale delle Ricerche (IGG-CNR) Padova, c/o Dipartimento di \\ Geoscienze, Università di Padova, Via Gradenigo 6, I-35131 Padova, Italy; tateo@igg.cnr.it
}

Received: 20 October 2020; Accepted: 26 November 2020; Published: 30 November 2020

\begin{abstract}
The Paleocene-Eocene Thermal Maximum (PETM) was an "extreme" episode of environmental stress that affected the Earth in the past, and it has numerous affinities concerning the rapid increase in the greenhouse effect. It has left several biological, compositional, and sedimentary facies footprints in sedimentary records. Clay minerals are frequently used to decipher environmental effects because they represent their source areas, essentially in terms of climatic conditions and of transport mechanisms (a more or less fast travel, from the bedrocks to the final site of recovery). Clay mineral variations at the PETM have been studied by several authors in terms of climatic and provenance indicators, but also as tracers of more complicated interplay among different factors requiring integrated interpretation (facies sorting, marine circulation, wind transport, early diagenesis, etc.). Clay minerals were also believed to play a role in the recovery of pre-episode climatic conditions after the PETM exordium, by becoming a sink of atmospheric $\mathrm{CO}_{2}$ that is considered a necessary step to switch off the greenhouse hyperthermal effect. This review aims to consider the use of clay minerals made by different authors to study the effects of the PETM and their possible role as effective (simple) proxy tools for environmental reconstructions.
\end{abstract}

Keywords: clay minerals; Paleocene-Eocene; greenhouse; climate; sediment provenance

\section{Introduction}

The Paleocene-Eocene Thermal Maximum (PETM) was a global warming event with very intense environmental effects. It was considered a climatic aberration, and recognized as one of the most prominent climatic event in the last 64 million years [1]. It took place over a very short time, especially the initial part, but also during the recovery towards pre-event conditions (overall, approximately 200,000 years [2]). In addition to the geological perspective, the PETM event is highly relevant to the present and near future, as it shares several features with industry-induced greenhouse conditions caused by the massive liberation of $\mathrm{CO}_{2}$ into the atmosphere [3], even though there are distinctive differences between the two [4]. In particular, these features include the massive input of carbon, the acidification of oceans, and the increase in global temperature by about $5-8{ }^{\circ} \mathrm{C}$, within a few thousand years (ky) [5]. These features deeply affect the climate of land areas and, thus, the mechanism of soil formation, which links the PETM climate to equally extraordinary effects on clay mineral formation during PETM pedogenesis. Clay mineral formation in soil environments is sensitive to bed rock composition and to the climatic regime of the area [6,7], but other environmental conditions can also play a role (such as microbial activity, kinetics of water-rock interaction, and topographic stability, among others). Climate sensitivity in particular has prompted several authors to use clay mineral assemblage as a tool for paleoclimatic studies, based on codified criteria [8], although, considering the complexity of climate reconstructions and of soil genesis, the use of clay minerals as a paleoclimatic tool in sedimentary successions has been strongly criticized [9]. Since the early understanding of the PETM's significance in the history of the Earth [10], many studies on the PETM have included clay 
mineral analyses with variable purposes, ranging from simple lithologic description to more complex evaluations. These works take advantage of another peculiar feature of the PETM that is marked by a rapid and powerful isotopic shift in oxygen and carbon chemostratigraphy. For this reason the identification of the PETM event can be accurately identified and calibrated in sedimentary successions with other stratigraphic features (such as biostratigraphy).

The aim of this work is to consider the use of clay minerals as a tool for broad geological studies in the context of a hyperthermal event (the PETM) that is very short in time, intense, and globally recognizable. The PETM event impacted the land and marine environments, and is regarded as a possible trigger for powerful weather pulses that facilitated a significant sink of $\mathrm{CO}_{2}$, allowing the climatic system to recover from the hyperthermal greenhouse conditions towards pre-event environments.

\section{Materials and Methods}

In order to identify the materials suitable for the review, the Web of Science database was consulted at the end of 2019 using a combination of two terms dealing with the mineralogical side ("clay minerals" or "minerals") and with the stratigraphic aspect ("PETM" or "CIE" or "Paleocene-Eocene" or "Paleocene" or "Eocene"). The final object of this search was to select papers containing stable isotope data used to identify the PETM and clay mineral analysis. For papers published in different years by the same research group, the most recent one was used. Additional works were considered if they discussed the significance of clay minerals related to the PETM. Other papers dealing explicitly with the clay minerals at the PETM were included if accurate biostratigraphic data were used and calibrated with the isotopic record. The final result was a list of 41 papers, published from 1991 to 2018.

\section{The PETM Event}

As a review of the literature about the multifold significance of the PETM is beyond the scope of this work, only essential features are reported. As one of the most catastrophic events of the last 64 million years, it affected marine and terrestrial biota (animal and vegetal) as well as the mineralogical and chemical composition of the sedimentary record. A comprehensive review dealing with the changes in carbon cycle, paleoclimate, and biota was carried out a few years ago [5], as well as a more specifically focused study on climate and marine productivity [11]. Other terminology that may be encountered to indicate the PETM event include the Latest Paleocene and Initial Eocene Thermal Maximum (LPTM and IETM, respectively), all of them refer to the short-term global warming event (about $200 \mathrm{ky}$ ) at about 56 million years (My), which is encompassed within a longer warming period (some million years long) culminating in the Early Eocene Climatic Optimum [1]. The PETM initiation is recognized by an abrupt shift in the carbon isotope record (termed carbon isotope excursion, CIE) of about $-4.7 \pm 1.5\left(\delta^{13} \mathrm{C} \%\right.$ o $)$ for marine records, and of about $-2.8 \pm 1.3 \%$ on land areas, whereas a similar and contemporaneous sudden decline in the oxygen isotope ratio (as $\delta^{18} \mathrm{O} \%$ ) is the key that indicates global warming, computed in $3-4{ }^{\circ} \mathrm{C}$ for surface oceanic waters, and approximately $6{ }^{\circ} \mathrm{C}$ for deep waters [5].

\subsection{Causes and Triggers}

The isotope carbon shift during the PETM is commonly attributed to a giant input of isotopically light carbon into the ocean-atmosphere system, on the order of 4-15 $\times 10^{12}$ tons [5]. The most notable effect of carbon input to the oceans was the acidification of waters and the increase of atmospheric $\mathrm{CO}_{2}$. Water acidification caused shoaling of the calcite compensation depth (CCD) by more than $2 \mathrm{~km}$, marked by the sedimentation of a clay layer more or less devoid of carbonates [12], with possible burndown of the underlying sediments [11]. The increased concentration of the $\mathrm{CO}_{2}$ into the atmosphere induced greenhouse global warming (up to 1000-5000 ppm $\mathrm{CO}_{2}$ ) [5].

A reservoir of such vast amounts of carbon, and with adequate isotope ratio to explain the degree of ocean acidification, the increased temperature and the final carbon isotope ratio observed at the PETM are difficult to be identified (also considering that such a huge volume of $\mathrm{CO}_{2}$ should be liberated 
in a very short time; an event not registered at any time in the Cenozoic Earth history). However, finding a suitable source of light carbon is only part of the problem, because a trigger mechanism must also be ascertained. As the enormous amount of carbon required, a few possible sources are as follows ([5] and references therein): (i) methane clathrates are stored in marine sediments at sub-bottom depths and can be destabilized by increased temperature or decreased pressure (for example changes in ocean circulation, basin uplift, slope failure, etc.); (ii) wildfires of biomasses could provide enough carbon, but traces of such combustion are scarce; (iii) thermogenic methane liberated by the intrusion of magma into organic-rich sediments (a possible scenario is the development of magmatic activity in the northern Atlantic); (iv) permafrost thawing at high (paleo)latitudes, induced by climatic conditions developed during periods of high eccentricity and obliquity. Other triggers, such as extraterrestrial impacts have been proposed [13], but proof at the global scale is lacking [14].

\subsection{PETM Divisions and Durations}

On the basis of analytical results (such as stable isotope data, paleontological associations, sedimentation rates, chemical compositions, etc.) the PETM stratigraphic interval has been divided into different portions that may correspond to lithological changes. They represent the macroscopic prevalence of distinct mechanisms operating in the source areas and in the basin, but their temporal lengths could partially overlap (for example the carbonate dissolution and the recovery of biogenic productivity could share a common time period, even if dissolution started earlier and recovery terminated later). The fist interval is represented by a precursor event, which shares similar isotopic features with the PETM event, but an isotope shift of lesser intensity that anticipates it by a few ky [15]. This short time lapse prevents precise identification of a single precursor event with respect to other fluctuations of the isotope record in the same time interval. For this reason, any perturbations just before the main isotopic shift could be considered as possible precursors of the PETM or just as normal oscillations of the system.

As already mentioned, the main body of the PETM event is marked by an abrupt shift in the carbon isotope record toward lower values of the $\delta^{13} \mathrm{C}$ (CIE onset), followed by a period during which these very low values are maintained. This interval represents the core of the PETM [2] and there are cases in which the parametric values are modulated by a variability of shorter length (Italy [11], Southern Ocean [16,17] and South Atlantic [2,17,18]), where these variations are considered as background astronomical effects. According to this view, a cyclostratigraphic approach was used to estimate the duration of the PETM core period, which has been estimated as lasting about $100 \mathrm{ky}$ for both marine and continental domains [18]. The duration of the PETM core period was assessed using the flux of extraterrestrial Helium as well, and obtaining similar results (about 90-110 ky) [2,16]). Whether the core duration is long enough to be measured in terms of precessional cycles (about $21 \mathrm{ky}$ each), the CIE onset is too rapid to be computed by the same unit and may possibly have been affected by post-depositional alterations, so only tentative estimates from less than $10 \mathrm{ky}$ (marine sites) to 8-23 ky (continental records) have been proposed [5]. The duration of the PETM onset is significant for the interpretation of the clay mineral assemblage, as the time necessary for clay formation in soils is a critical parameter [9].

A remarkable feature of the PETM onset is the severe carbonate dissolution and undersaturation of oceanic waters, which developed in fewer than $10 \mathrm{ky}$, shoaling the calcite compensation depth by about $2000 \mathrm{~m}$ [12]. Global acidification of marine waters likely also affected terrestrial rain water, with possible consequences for the pedogenic regime, including clay mineral formation [19]. Ocean acidification also coincides and accounted for the major extinction event of benthic foraminifera in the last $90 \mathrm{My}$ ([20] and references therein), whereas other groups of benthic and planktonic microfossils did not become extinct during the PETM, although terrestrial and other marine organisms underwent significant modifications and crisis [5]. The great increase in abundance and geographic distribution of the dinoflagellate Apectodinium is one of the most salient observations of the PETM, and this phenomenon is considered to have been caused by a number of different possible factors, 
such as higher ocean temperatures, increased continental runoff, water (and salinity) stratification, and eutrophic conditions in coastal waters [21]. Many of these observations also fit two other features reported for the PETM: (i) the increase in the terrigenous sedimentation rate [20], possibly connected to the increased erosion of soil and soil substrates, and (ii) the accumulation of organic matter, possibly caused by high productivity, which acts as a feedback to restore $\mathrm{CO}_{2}$ levels to pre-PETM values [3].

The rapidity of the PETM onset and its possible similarities with modern global warming prompted high resolution sampling of the most critical intervals. In particular, the PETM onset and the initial part of the core portion show several lithological and compositional variations (including clay minerals) within a few centimeters or less (see examples from the North Sea [22,23], Egypt [24-28], New Jersey [29,30], Italy [31], New Zealand [32], and several sections belonging to the Tethyan realm [33]). These high-frequency variations of the mineralogical composition preclude a precise identification of single episodes because no chronostratigraphic tools can firmly discriminate among them.

Subsequent to the main isotope excursion (core PETM), the $\delta^{13} \mathrm{C}$ values gradually returned toward pre-PETM conditions. This stage, generally referred to as "recovery", is normally more gradual then the onset, and remains so until termination of the PETM event. For this reason the duration of the recovery is difficult to define, but approximately $100 \mathrm{ky}$ is a possible reference time [2]. A unique value of $82 \mathrm{ky}$ was postulated for continental and marine domains [18], although a longer time period (120 ky) has been recently proposed [34]. The recovery period is significant for the Earth climate because the return to normal conditions implies an effective mechanism of carbon extraction from the atmosphere-ocean domain and a sink into other compartments not affecting the climatic system (for instance, the deep burial of organic carbon, carbonate sediments, the development of permanent forests, peat deposition, etc.). More intense continental weathering is a possible process that improves the sequestration of $\mathrm{CO}_{2}$, so it is reasonable to consider that clay minerals formed in the soil recorded this particular and extreme climatic condition [35] that lasted for about $100 \mathrm{ky}$, albeit with decreasing degrees of intensity toward the final part of the recovery. A stronger degree of weathering agrees with more abundant rainfall and higher temperatures, believed to facilitate the diffusion of the dinoflagellate Apectodinium, which actually proliferated during the PETM [36].

\section{Results of Reviewing the Literature}

The results of the literature examination are reported in Table S1 [11,19,22-33,35,37-62], which focuses on simplified lithological framework, clay mineral composition, physical-chemical properties, and their interpretations. The quantitative changes of clay minerals in the PETM at onset and recovery are also concisely described and will be briefly discussed in the text. By contrast, some possibly critical or significant features are evaluated in more detail, in order to interpret clay minerals within a specific context of the PETM. The mineralogical association described in the papers is considered by the authors devoid of significant post-depositional transformations, although a few works address the issue explicitly with reference to possible mineralogical changes by diagenesis $[19,22,26,31,33,37,38,40,41,58,59]$.

Identification of the PETM onset is the first point considered in the table because it is not obvious, as in many cases, the dissolution of carbonates prevents measurement of $\delta^{13} \mathrm{C}$ in foraminifera tests, or in the bulk sediment, so organic materials have to be used instead. A methodological note is also reported dealing with the materials used for clay study. This information turned out to be significant even when, in the early studies, the "classic" clay fraction was used $(<2 \mu \mathrm{m}$, with the sum of clay minerals as $100 \%[37,38])$. In other cases, the grain size fraction was different, or not specified, or the clay minerals were computed for the bulk rock, without sum recalculation. The parameters used to discuss the significance of clay minerals as possible climatic indicators are also shown, as they can be very different (relative amount, mineral ratios, \% of illite in mixed layers, crystallographic ordering, etc.). Since the variations in kaolinite are often mentioned as a key parameter in the PETM, this is reported in more details. The method for mineral quantification was variable, but the details are 
not reported in Table S1, because the significant information was the mineral variations and not the quantity. A brief reference to analytical methods is reported in the following text for salient features only. Finally, though synthesis of the interpretation is considered, it should be clear that the scheme in the table is not at all exhaustive of the discussion done by the authors, and should be generalized outside the domains they considered. Whenever the clay mineral compositions are used as a tool for climatic or provenance study, they are mentioned and schematically reported as "climatic-oriented" or "provenance-oriented".

\subsection{The "Clay Fraction"}

A routine procedure in the study of clay minerals is the concentration of them by grain size separation. For many decades, the fraction $<2 \mu \mathrm{m}$ has been considered a reference for geological and environmental studies $[63,64]$, coinciding with benchmark works on marine sediments $[65,66]$. In the latter paper, the silicate minerals found in the $<2 \mu \mathrm{m}$ fraction are labeled as "clay fraction", and in the subsequent years this concept become a formal definition of "clays" within the mineralogical disciplines ("naturally occurring material composed primarily of fine-grained minerals..." [67]). This is primarily a sedimentological definition based on grain size. A further consideration concerns minerals formed in the soil environment, which are mainly fine grained, so the possible climatic signal transferred from soils to sediments can be studied in such particular fraction (see for example [8,68-70]). Many papers report the complete mineralogical composition of the clay fraction (several works, see Table S1), often with the additional aid of selected mineral ratios, which are significant for provenance or climatic interpretation [22,24,32,40,41,44,58,62]. A few works adopt a different approach, focusing on the bulk materials $[25,26,45,47]$, or using the bulk sediment as well as the clay fraction, applying similar interpretation scheme [49,50]. Clearly, mineral variations in the bulk could affect different grain size fractions to unknown degrees. Curiously the works discussing mineralogical data on bulk sediment are concentrated within a narrow time frame (2011-2013). Occasionally a generic term such as "clay fraction" is used instead of precise grain size limits.

The separation of a fine grain size fraction and the quantification of its silicate minerals represent a sort of "classic" approach for clay mineral study $[65,66]$. It also has a further aftermath, which is the closed system, i.e., the sum of the clay minerals equals $100 \%$, despite the occurrence of other minerals into the same grain size class. For this reason mineral ratios are used most frequently as reference parameters rather than indicating the quantitative variation of a single mineral. From this standpoint, the quantification of mineral abundances for the bulk materials makes it more difficult to compare them with other studies focused on the clay fraction, even within the same data set, because the variation of a mineral in the bulk could be affected by a simple dilution or concentrations determined only by non-clay mineral fluctuations (carbonate variation or mineral segregation into different grain size classes).

\subsection{Methodological Approaches to Clay Mineral Quantification}

The methodological section is not completely detailed in all of the papers; this disparity may be due to the purpose of research/study or editorial/journal policy, or both.

All of the studies cited in Table S1 used X-ray diffraction (XRD) techniques for mineral evaluation, and in most cases, the clay fraction was analyzed in untreated, glycolated (rarely glycerolated), and heated conditions, as is commonly done [65,66,71]. Following mineral identification, the minerals ratio was obtained by measuring mineral concentrations, or by using the XRD peak intensities [33,37,38,62], as the aim of the study was for comparative purposes. Only two papers implemented a more sophisticated approach [22,55] with the NEWMODC for Windows software [71].

In a few papers, a Rietveld refinement procedure was used for the bulk material $[25,26]$. However, this refinement can be very time consuming, so, in order to get only a mineral ratio (for instance kaolinite/chlorite), rather than calculating the complete mineralogical abundances by full pattern fitting 
or by Rietveld procedures, the choice was to adopt a simpler routine measurement, without diminishing the results presented [50].

In a few contributions, the mineralogical composition of the clay fraction is reported as XRD traces only [25,39], or is accompanied by accurate quantitative mineral data relative to the bulk. In this case, the distinction among different phyllosilicates usually intended as clay minerals, such as illite, smectite, kaolinite, and chlorite is presented [26].

As could be expected, according to different methodological approaches, the mineral abundances may not be comparable among the different studies, but this is not critical, as only relative variations among samples of the same set are considered significant. An exception is represented by the extraordinarily high amounts of kaolinite detected at the PETM onset in both the North Sea and Spain, which is stressed by the author [61] (Figure 1). Nevertheless a direct numerical comparison with clay mineral abundances in modern environments was mentioned only in an early/pioneer paper [32].

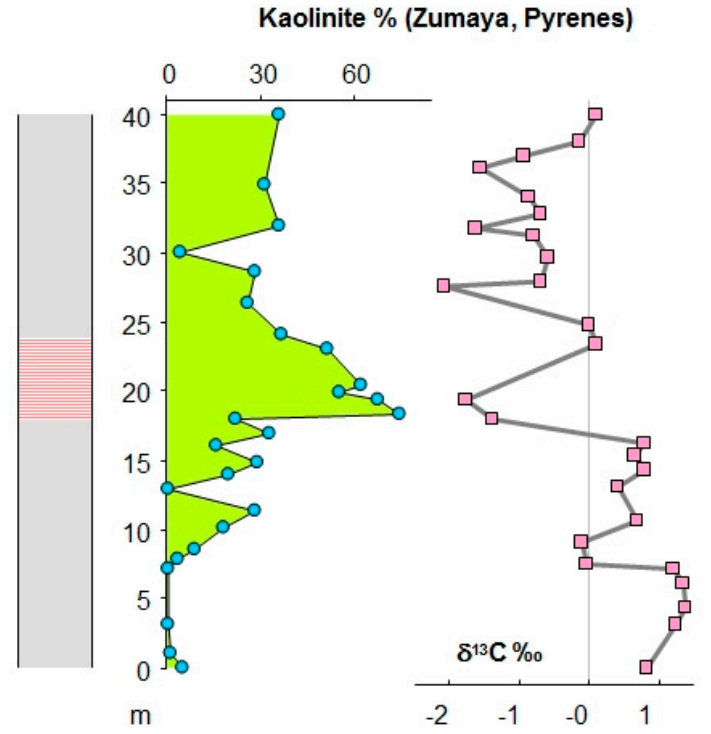

(a)

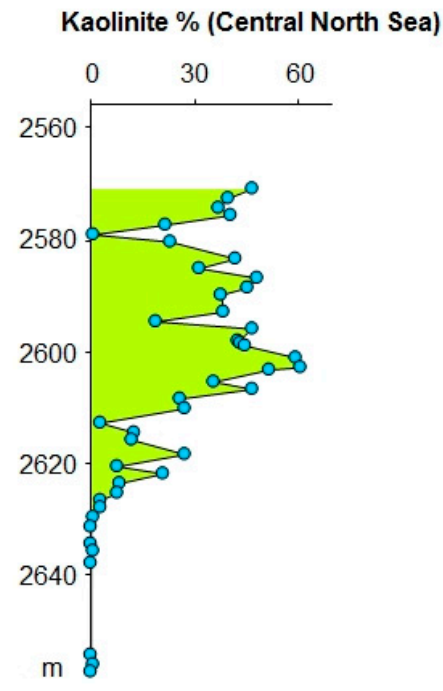

3 4
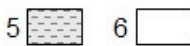

(b)

Figure 1. Examples of the clay mineral expression at the Paleocene-Eocene Thermal Maximum (PETM) showing strong increase of the kaolinite content, from almost zero up to $>60 \%$ (grain size not specified); simplified lithology: 1 = grey mudstone/marl with turbidites; 2 = red-brown unit; 3 = sandstone; 4 = laminated dark-gray mudstone; 5 = poorly laminated grey mudstone; $6=$ unbedded grey-green and red mudstones; redrawn from [61]. (a) Zumaya, Pyrenes; (b) Central North Sea

\subsection{The Kaolinite Pulse at the PETM}

The increase of kaolinite content with respect to that of other clay minerals in the $<2 \mu \mathrm{m}$ fraction, which was correlated with lower $\delta^{18} \mathrm{O}$ of benthic and planktonic foraminifera [38], became a basis of success for the use of clay minerals in the PETM study. Looking at the results reported in Table S1, in many cases all over the world, an increase of kaolinite is detectable through the PETM interval, sometimes with patterns similar to those observed in the early study $[29,30,32,42,44,46,47,50,61]$ : a good match between the variations of the kaolinite abundance and carbon isotope variations (Figure 2A) or an overall significant increase of kaolinite or kaolinite index during the PETM (see for instance Figure 2B, in such case both for the bulk and the $<2 \mu \mathrm{m}$ fraction). Nevertheless, different trends also occur, with more complex relationships between clay minerals and isotopic data $[19,22,24,27,28,31,35,37,41,43,45,48,49,53,56-58,62]$ (Figure 3). 

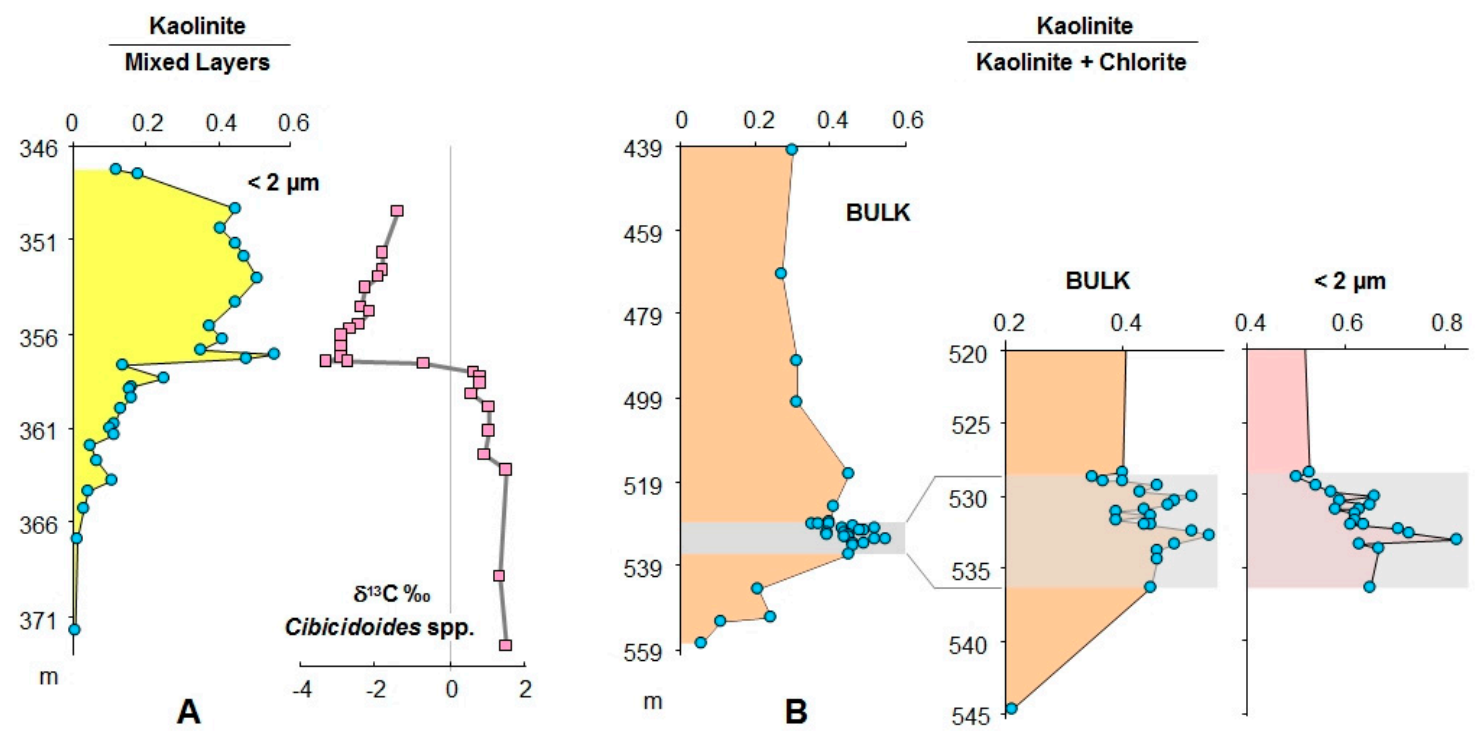

Figure 2. Examples of the clay mineral expression at the PETM showing clear variations of kaolinite; (A) Bass River borehole (New Jersey): a sharp pulse of the kaolinite-mixed layers ratio is contemporaneous to the main $\delta^{13} \mathrm{C}$ shift and a later pulse of the same ratio develops during the recovery of $\delta^{13} \mathrm{C}$ values toward pre-PETM values (redrawn from [30]); (B) Svalbard: the kaolinite—chlorite ratio (computed between 0 and 1 ) is higher during the interval identified as the PETM (grey band); in the enlargement on the right the mineral ratio in the bulk sediment and in the $<2 \mu \mathrm{m}$ fraction are reported showing similar oscillations and trends (redrawn from [50]).

The comparison among different data sets is strongly hampered by different sampling intervals or resolutions, which make it impossible to reflect the local variability of the clay minerals, masking the ephemeral, but evident mineral changes as exemplified by the data from Egypt [24,26,28] (Figure 3A). Another possible point of weakness is the mismatch of the sampling position used for different proxies throughout the same succession (for instance the isotope and the mineral records), which could cause a tendency to overlook short-lived events. The advisability of comparing different sites studied with homogeneous criteria and laboratory approaches is highly recommended; it is then possible [33] to identify a diachronic succession of clay mineral variations in the Tethys, in response to the local/regional effect of global climatic stresses, even when homogeneous conditions can be traced along a more restricted domain.

Another possible trace of weathering intensification is marked by a significant kaolinite increase during the PETM recovery at high (paleo)latitudes, coinciding with coccolithophore carbonate sedimentation and the Acarinina subsphaerica acme [35]. A kaolinite pulse of this type is difficult to recognize in most other sites, and was largely ignored, because the studies cited focused on the strongest isotope shifts at PETM onset. At some sites, the clay mineral data seem consistent with this hypothesis $[22,29,30,32,49,50,62]$, although a proper sampling of the recovery interval would hopefully yield more definitive considerations. 


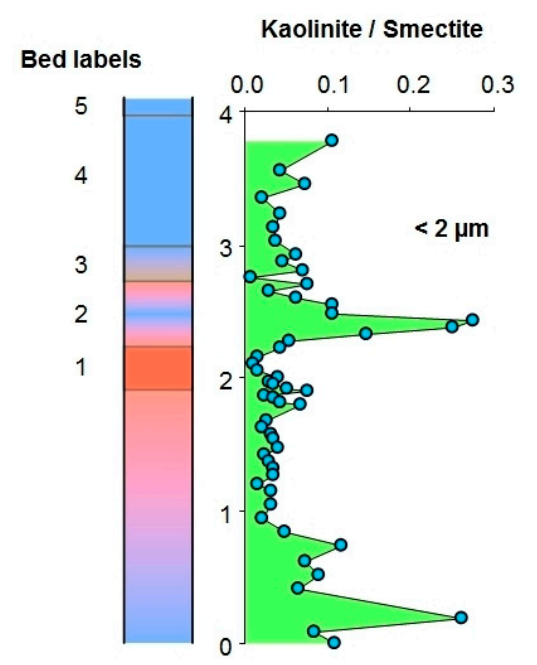

Palygorskite \%
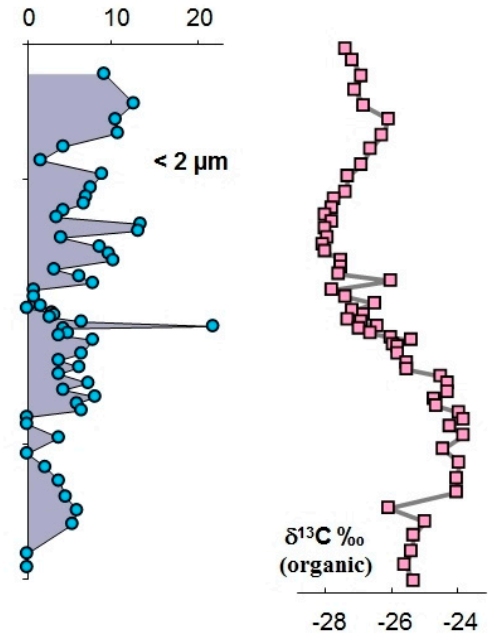

A

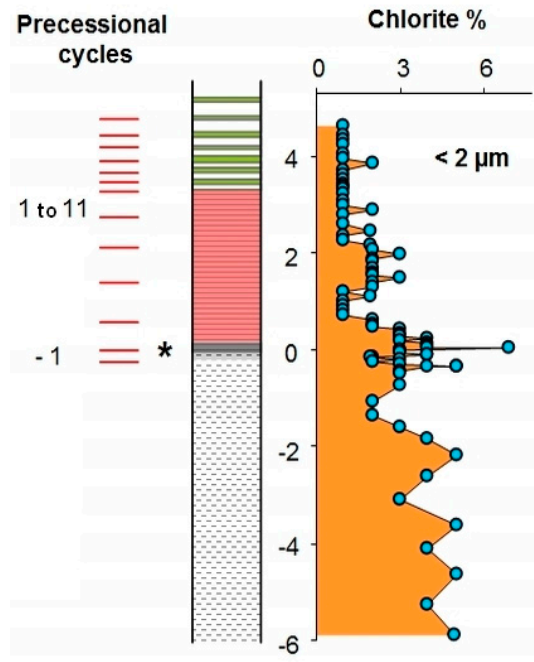

Kaolinite \%
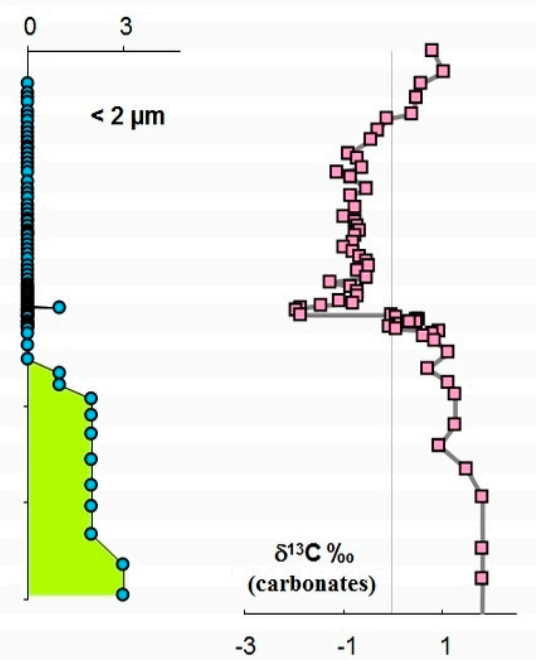

B

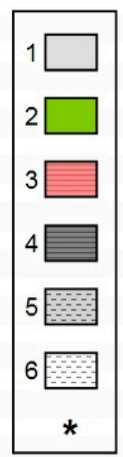

Figure 3. Examples of high-resolution sampling for clay mineral analyses at the PETM; (A) Dababiya NW (Egypt): the palygorskite variability through the section is detectable, with short intervals of absence; a short-lived episode of an enhanced kaolinite-smectite ratio is detectable during the maximum lightning of the carbon isotope composition; the chromatic effects column suggests further subdivisions within some of the bed (redrawn after [50], see also Table S1 for a schematic summary of bed labeling); (B) Forada section (Italy): the $\delta^{13} \mathrm{C}$ carbonates oscillations at cycle $-1,1$, and 2 are accompanied by opposite chlorite variations despite the very low content of the mineral; the very base of cycle 1 (black shale) is detectable by a sharp pulse of chlorite and kaolinite (single sample); simplified lithology: 1 = limestone; 2 = marl; 3 = clay-marl; 4 = laminated clay to marly clay; $5=$ marl (partially decarbonated); $6=$ marl; ${ }^{*}=1 \mathrm{~mm}$ thick black shale (base of cycle 1); redrawn from [24].

\subsection{The Clay Mineral Signal at the PETM as a Paleoclimatic Tool?}

Paleosols developed throughout the PETM period provide a good opportunity to test the clay mineral composition as a tool for paleoclimatic reconstructions. Unfortunately, the discontinuity and difficulty in dating paleosols reveal only a partial or fragmented picture. Although several studies $[40,51,52]$ are concordant in recognizing clay minerals as viable climate proxies, there remain two main critical features: the possible detrital origin of clays [40,52] and the short time needed for kaolinite formation under extreme climatic and physical-chemical conditions during the PETM (such as soil $\mathrm{pH}$ ) [51]. These two issues remain unresolved, or the final interpretation needs the 
additional support of other kinds of data, such as the textural characteristics observed under the scanning electron microscope + energy dispersive system. Textural data revealed the detrital origin of illite (anhedral plates), whereas smectite and kaolinite were recognized as pedogenic, according to their occurrence as flakes (smectite) and as booklets of plates (kaolinite) in samples richer in kaolinite [41]. Moreover, the occurrence of well-developed booklets of platy kaolinite surrounded by packets of smectite made it possible to define a relative order of formations.

A few studies on clay minerals from continents and transitional environments have been published. The most recent one involved clay from extended and continuous lake sediments (approximately $18 \mathrm{~m}$ thick) [41], where the PETM onset is marked by a rapid increase of the kaolinite/smectite ratio, which then decreases with scattered values toward pre-PETM values at the end of the recovery. There is a rather good match between the kaolinite/smectite ratio and the paleotemperature based on organic geochemistry indices and also with the chemical index of alteration (CIA), but to a lesser extent. The final considerations include the feasibility of clay minerals as tool for paleoclimate studies, even if a caveat is underlined, dealing with different conditions that can arise in different geographic positions and climatic zones. Three other studies focus on shallow marine or transitional environments, with erosive surfaces and hiatuses $[42,57,60]$. In all of them, an overall increase of kaolinite content is observed at the PETM, very noticeable [42], or accompanied by an increase in chlorite (Esplugafreda, Spain) [57] or with illite (New Jersey) [60]. The interpretations proposed are quite different. The occurrence of carbonate nodules and gypsum in coeval Spanish soils strongly disagrees with a climate favoring the formation of kaolinite, so the increase of kaolinite in the Spanish sections is considered a product of the erosion of Cretaceous lateritic deposits [42,57]. On the contrary, a climatic signal is recognized for New Jersey sediments, taking into account (among other features) that the kaolinite variations have similar shape and intensity through different sites, and represent distinct catchments composed of different substrate rock. The rapid pedogenic formation of kaolinite is considered compatible with very aggressive climatic conditions. Despite the opposite interpretations of the kaolinite origin in Spain and New Jersey, the use of the kaolinite pulse as a correlation tool is proposed by several researchers $[42,60]$.

For continental sediments, the coexisting soil or source areas represent valuable references, whereas for marine materials, the sediment provenance can be highly variable in terms of distance from source rocks and possible grain size segregation, so the significance of clay minerals is more difficult to decipher $[8,69]$. As summarized in Table S1, the clay mineral signal at the PETM onset and recovery is far from being homogeneous or synchronous. Indeed, the final interpretation in most studies is a result of integrated discussion of lithological, compositional, biological, and other data. Nevertheless, when the contribution of clay mineral data is relevant to the final interpretation this is mentioned in Table S1. In a few cases, both the erosion of previously formed clay minerals and neoformation in soil are considered valid explanations of the observed mineral assemblage, dealing with: (i) uncertain significance of the clay minerals $[23,29,30,58]$ or (ii) different weight of newly-formed clays in soil and erosion, resulting in different significance of the clay minerals within the same succession $[53,54]$. The latter condition is especially appropriate for the PETM, where strong lithological and compositional changes occur over short time spans, as observed for example in Egypt [24-28,44,53,56], Italy [11,31], and New Zealand [32].

Although many studies focus on kaolinite in the PETM interval, fibrous clay minerals (palygorskite and sepiolite) occur in high to intermediate paleolatitude sites (Egypt [24,28], Israel [33,44], South Spain, Tunisia [33], and at DSDP (Deep Sea Drilling Project) site 530 in the Angola basin [38]). Their genetic environment is far from kaolinitic soils: warm and arid climatic conditions are required to form these fibrous clay minerals, excluding hydrothermal transformations [33], so palygorskite and sepiolite have potentially high climatic significance.

It is worth mentioning that other physical-chemical parameters or non-clay minerals have been used in a few studies as proxies for reconstructing the paleoclimatic conditions or paleoenvironment of clay formation (see Table S1). A few studies consider other clay mineral features independently of their concentrations, such as clay mineral textures [40], crystallographic ordering [22,26,45,49], 
or stable $(\mathrm{O}, \mathrm{H})$ [46] and radiogenic (Os) [45] isotope compositions of clays. The use of chemical indexes of the weathering intensity is implemented $[41,44,45,51]$, whereas biochemical markers are restricted to relatively recent papers only $[11,41,46,47]$. The support of these tools often agrees with a climate-oriented interpretation of the clay mineral assemblage $[26,40,41,44,45,51]$, but this is not conclusive, as different interpretations can be found [22,26,46,47].

\section{General Discussion}

The PETM event, being very brief in time (approximately $200 \mathrm{ky}$ ), precisely identified throughout the geological record by isotope stratigraphy and representing an extreme climatic regime (no ambiguous conditions), could be an appropriate period to test the response of clay minerals under intense climatic stress affecting the Earth globally. However, as reported in Table S1, the expression of clay minerals is not consistent throughout the studied sites and the interpretation varies between two poles: inheritance from older eroded substrates and syndepositional formation in soils, which is the balance between the velocity of soil dismantling and soil-mineral neoformation. These two processes are always active and well documented in numerous reference treatises $[8,68,69,72]$. The problem is to determine the most effective process. Several criteria have been adopted to unscramble the clay mineral signals (Table S1). Systematic analyses of possible confounding mechanisms is an effective approach (for example through the Tethyan realm [33], or for single sites [37]), and can lead to detection of significant processes that alter the clay mineral assemblage trough the transport path [73]. Another point is that the time needed for kaolinite to develop in soils is possibly significantly longer [9] then the brief PETM event [26,46,48]. Alternatively, increased hydrological cycles lead to enhanced erosion and sediment transport of older, more deeply weathered bedrocks and soils [46]. Moreover, a hyperthermal world with acidified ocean-atmosphere waters would trigger faster kinetics in soil mineral formation $[50,51,60,62]$, so the time-lapse criterion is not commonly accepted in the PETM case.

An example of contentious interpretation of the clay mineral data, integrated with several other observations for Spanish sections [59], suggests that the clay mineral assemblage alone is hardly conceivable as a tool for environmental reconstruction. This conclusion does not diminish the reliability of what could be considered the "climatic paradigm" of clay formation in soils. The early works relative to the PETM clay composition (see for example [38]) report the main concepts noting, in particular, that kaolinite develops in highly weathered continental areas, where leaching by running water favors the hydrolysis of the substrate-rocks and the removal of alkaline and alkaline-earth elements, which are most mobile under particularly acidic conditions. A similar genetic environment of kaolinite matches with the expected climatic conditions of hyperthermal event in non-arid areas, and may have prompted the attention on kaolinite occurrence in the PETM, but several critical features were expressed with particular attention for the PETM interval [74]. In general terms, the possible interplay among factors determining the final mineral composition of marine sediments is well known (see for example [75]).

Moreover, palygorskite and sepiolite deserve attention in climatic reconstructions during the PETM event, as these minerals occur in sites at low latitude during the PETM $[24,33,37,38,44]$ and are considered mainly formed in warm and poorly drained regions subjected to long dry seasons [69], in calcretes, in coastal or lacustrine areas with alkaline $\mathrm{pH}$, and water evaporation [38]. As for the other clay minerals, the climatic significance of palygorskite and sepiolite may be confounded by reworking [76], but morphological observations can help in deciphering whether fibrous clay minerals were subjected to a long transport process [77]. It is rather interesting to note that the occurrence of palygorskite and sepiolite (among other features) was used in an early paleoclimatic reconstruction of the PETM [38] to hypothesize that "warmer conditions were associated with enhanced evaporation at low to middle latitudes, and increased precipitation at high latitudes"; a conclusion that is consistent with a review published about 30 years later that, combining multidisciplinary climatic records available up to the present time, indicates a "decrease rainout at subtropical to mid-latitudes, and increase moisture transport toward the high latitudes" [11]. 


\section{Conclusions and Developments}

The PETM interval is a short time span in the geological history (a few precessional cycles), but was characterized by many great environmental-biological events that can only be identified by high resolution sampling of the sedimentary records. Even in this case, relevant events can be missed, making the comparison between different sites rather difficult or incomplete, as a short-lived mineral pulse could easily be missed in low resolution sampling. Despite this possible complication, it seems clear from the literature reviewed that the main isotopic shifts for carbon and oxygen are commonly recognizable in marine and continental realms, and in all the materials considered (total carbonates, benthic or pelagic foraminifera, total organic carbon, selected plant molecules); on the contrary, the record of clay minerals record is not so homogeneous, even in sites relatively close to each other (see for example $[19,31,58]$ ). The clay mineral assemblage depends on the climatic regime, but also on the local arrangement of exposed terrains and marine circulation (at least). For this reason, a synchronous effect on the clay mineral composition, as observed for isotopic signals, may not always be detectable. For instance, detailed reconstruction through the Tethyan domain [33] identifies diachronic expression of a humid climate just prior to the PETM and the maximum kaolinite signal at the PETM also correlates better only in the southwestern Tethys. In this case, the mineral association could be envisaged as the modulation of the global climatic regime through a range of local effects, in a regional framework, not excluding distant areas whose eroded materials can be transported some distance from the source zone. Other mechanisms are also known to modify the mineral association in sediments, such as the mineral aggregation [69] or grain size sorting [78,79].

An additional feature that could be considered for more confident use of the clay mineral assemblage for provenance and climatic studies is the comparison with modern soil and sediment composition. An example developed over a broad continental area refers to North America (United States and Canada): the bulk fraction of the A and C soil horizons along an east-west transect shows a decrease in feldspar content related to increased precipitation eastward, and has little relationship with the underlying parent material, although in the more arid regions, west of the Rocky Mountains, the composition of the soil parent material is more effective; no other significant mineral-weathering relationship is highlighted [80]. The effects of the parent materials and river transportation, deposition and remobilization are evidenced also in the clay fraction of sediments throughout the Amazon River catchment, apparently more efficacious then climatic conditions in controlling the clay mineral assemblage [81]. The interplay between source area with their particular substrate rock composition and climate is highlighted in several works (for instance in the Mediterranean [82] and China Sea [83,84]), showing how the clay mineral assemblage is sensitive to these different environmental parameters. An additional perspective could arise from new mineral proxies, which are being proposed [85], with the aim to more closely match specific weathering phenomena; they are based on the spectroscopic quantification of clay minerals and associated phases in clays: the chlorite/(chlorite + hematite + goethite) ratio, and the hematite/goethite ratio. The proxy considers that chlorite is more stable under dry, cold climatic conditions, whereas the action of chemical weathering releases the iron ions from the crystal lattice so that they easily precipitate as oxide or hydroxide under oxidizing conditions. The products of iron oxidation are regarded in the other proxy (hematite/goethite), based on the preferred formation of hematite in drier and warmer conditions, while goethite is favored by wetter and cooler climates.

Clay minerals can be effective indicators of the many processes that are significant in the sedimentary environment at the PETM, and the list of works in Table S1 shows that other companion proxies are going to increase in number and type, and will probably further increase in the future, facilitating finer tuning of mineralogical tools. However, a recent review of the PETM event [11] still reports clay minerals among five proxies used to infer hydrological changes. 
Supplementary Materials: The following are available online at http://www.mdpi.com/2075-163X/10/12/1073/s1, Table S1: Papers dealing with clay minerals at the PETM interval, following chronological order. The main features of the studied sites, methods, mineralogical results and data interpretations are reported. Abbreviations: $\mathrm{Chl}=$ chlorite, $\mathrm{CIA}=$ Chemical Index of Alteration; $\mathrm{D}=$ domain $(\mathrm{c}=$ continental, $\mathrm{m}=$ marine $)$; Ilt $=$ illite, $\mathrm{m} / \mathrm{c}=$ marine $(\mathrm{m})$ or continental $(\mathrm{c})$ materials; $\mathrm{ML}=$ mixed layers illite-smectite, $\mathrm{Kln}=$ kaolinite, $\mathrm{Plg}=$ palygorskite, $\mathrm{R}=$ reference; Sep = sepiolite, $\mathrm{Sme}=$ smectite, $\mathrm{XRD}=\mathrm{X}$-ray diffraction.

Funding: This research received no external funding.

Acknowledgments: The two anonymous reviewers and Guest Editor Francesco Cavalcante are acknowledged for their suggestions.

Conflicts of Interest: The author declares no conflict of interest.

\section{References}

1. Zachos, J.C.; Pagani, M.; Sloan, L.C.; Thomas, E.; Billups, K. Trends, rhythms, and aberrations in global climate $65 \mathrm{Ma}$ to present. Science 2001, 292, 686-693. [CrossRef] [PubMed]

2. Murphy, B.H.; Farley, K.A.; Zachos, J.C. An extraterrestrial ${ }^{3}$ He-based timescale for the Paleocene-Eocene thermal maximum (PETM) from Walvis Ridge, IODP Site 1266. Geochim. Cosmochim. Acta 2010, 74, 5098-5108. [CrossRef]

3. Dickens, G.R. The blast in the past. Nature 1999, 401, 752-754. [CrossRef]

4. Zeebe, E.R.; Ridgwell, A.; Zachos, J.C. Anthropogenic carbon release rate unprecedented during the past 66 million years. Nat. Geosci. 2016, 9, 325-329. [CrossRef]

5. McInerney, F.A.; Wing, S.L. The Paleocene-Eocene thermal maximum: A perturbation of carbon cycle, climate, and biosphere with implications for the future. Annu. Rev. Earth Planet. Sci. 2011, 39, 489-516. [CrossRef]

6. Wilson, M.J. The origin and formation of clay minerals in soils: Past, present and future perspectives. Clay Miner. 1999, 34, 7-25. [CrossRef]

7. Dixon, J.B.; Weed, S.B. Soil Science; Soil Science Society of America: Madison, WI, USA, 1989; p. 1245.

8. Wevear, C.E. Clays, Muds, and Shales; Elsevier: Amsterdam, The Netherlands, 1989; p. 819.

9. Thiry, M. Palaeoclimatic interpretation of clay minerals in marine deposits: An outlook from the continental origin. Earth-Sci. Rev. 2000, 49, 201-221. [CrossRef]

10. Kennett, J.P.; Stott, L.D. Abrupt deep-sea warming, palaeoceanographic changes and benthic extinctions at the end of the Palaeocene. Nature 1991, 353, 225-229. [CrossRef]

11. Giusberti, L.; Boscolo Galazzo, F.; Thomas, E. Variability in climate and productivity during the Paleocene-Eocene Thermal Maximum in the western Tethys (Forada section). Clim. Past 2016, 12, 213-240. [CrossRef]

12. Zachos, J.C.; Röhl, U.; Schellenberg, S.A.; Sluijs, A.; Hodell, D.A.; Kelly, D.C.; Thomas, E.; Nicolo, M.; Raffi, I.; Lourens, L.J.; et al. Rapid acidification of the ocean during the Paleocene-Eocene Thermal Maximum. Science 2005, 308, 1611-1615. [CrossRef]

13. Schaller, M.F.; Fung, M.K.; Wright, J.D.; Katz, M.E.; Kent, D.V. Impact ejecta at the Paleocene-Eocene boundary. Science 2016, 354, 225-229. [CrossRef] [PubMed]

14. Schmitz, B.; Peucker-Ehrenbrink, B.; Heilmann-Clausenc, C.; Aberg, G.; Asaro, F.; Lee, C.-T.A. Basaltic explosive volcanism, but no comet impact, at the Paleocene-Eocene boundary: High-resolution chemical and isotopic records from Egypt, Spain and Denmark. Earth Plan. Sci. Lett. 2004, 225, 1-17. [CrossRef]

15. Sluijs, A.; Brinkhuis, H.; Schouten, S.; Bohaty, S.M.; John, C.M.; Zachos, J.C.; Reichart, G.-J.; Damsté, J.S.S.; Crouch, E.M.; Dickens, G.R. Environmental precursors to rapid light carbon injection at the Palaeocene/Eocene boundary. Nature 2007, 450, 1218-1221. [CrossRef] [PubMed]

16. Farley, K.A.; Eltgroth, S.F. An alternative age model for the Paleocene-Eocene thermal maximum using extraterrestrial ${ }^{3}$ He. Earth Plan. Sci. Lett. 2003, 208, 135-148. [CrossRef]

17. Röhl, U.; Westerhold, T.; Bralower, T.J.; Zachos, J.C. On the duration of the Paleocene-Eocene Thermal Maximum (PETM). Geochem. Geophys. Geosyst. 2007, 8, Q12002. [CrossRef]

18. Westerhold, T.; Rohl, U.; Wilkens, R.H.; Gingerich, P.D.; Clyde, W.C.; Wing, S.L.; Bowen, G.J.; Kraus, M.J. Synchronizing early Eocene deep-sea and continental records-cyclostratigraphic age models for the Bighorn Basin Coring Project drill cores. Clim. Past 2018, 14, 303-319. [CrossRef] 
19. Egger, H.; Homayoun, M.; Huber, H.; Rogl, F.; Schmitz, B. Early Eocene climatic, volcanic, and biotic events in the northwestern Tethyan Untersberg section, Austria. Palaeogeogr. Palaeoclimatol. Palaeoecol. 2005, 217, 243-264. [CrossRef]

20. Giusberti, L.; Capraro, L.; Luciani, V.; Fornaciari, E. The Italian record of the Palaeocene-Eocene Thermal Maximum. Boll. Soc. Paleontol. Ital. 2019, 58, 85-108.

21. Sluijs, A.; Brinkhuis, H. A dynamic climate and ecosystem state during the Paleocene-Eocene Thermal Maximum: Inferences from dinoflagellate cyst assemblages on the New Jersey Shelf. Biogeosciences 2009, 6, 1755-1781. [CrossRef]

22. Kemp, S.J.; Ellis, M.A.; Mounteney, I.; Kender, S. Palaeoclimatic implications of high resolution clay mineral assemblages preceding and across the onset of the Palaeocene-Eocene Thermal Maximum, North Sea Basin. Clay Miner. 2016, 51, 793-913. [CrossRef]

23. Knox, R.W.O. Correlation of the early Paleocene in northwest Europe: An overview. Geol. Soc. Lond. Spec. Publ. 1996, 101, 1-11. [CrossRef]

24. Khozyem, H.; Adatte, T.; Spangenberg, J.E.; Keller, G.; Tantawy, A.A.; Ulianov, A. New geochemical constraints on the Paleocene-Eocene thermal maximum: Dababiya GSSP, Egypt. Palaeogeogr. Palaeoclimatol. Palaeoecol. 2015, 429, 117-135. [CrossRef]

25. Schulte, P.; Schwark, L.; Srassen, P.; Kouwenhoven, T.J.; Bornemann, A.; Speijer, R.P. Black shale formation during the Latest Danian Event and the Paleocene-Eocene Thermal Maximum in central Egypt: Two of a kind? Palaeogeogr. Palaeoclimatol. Palaeoecol. 2013, 371, 9-25. [CrossRef]

26. Schulte, P.; Scheibner, C.; Speijer, R.P. Fluvial discharge and sea-level changes controlling black shale deposition during the Paleocene-Eocene Thermal Maximum in the Dababiya Quarry section, Egypt. Chem. Geol. 2011, 285, 167-183. [CrossRef]

27. Soliman, M.F.; Aubry, M.P.; Schmitz, B.; Sherrell, R.M. Enhanced coastal paleoproductivity and nutrient supply in Upper Egypt during the Paleocene/Eocene Thermal Maximum (PETM): Mineralogical and geochemical evidence. Palaeogeogr. Palaeoclimatol. Palaeoecol. 2011, 310, 365-377. [CrossRef]

28. Dupuis, C.; Aubry, M.P.; Steurbaut, E.; Berggren, W.A.; Ouda, K.; Magioncalda, R.; Cramer, B.S.; Kent, D.V.; Speijer, R.P.; Heilmann-Clausen, C. The Dababiya Quarry section: Lithostratigraphy, clay mineralogy, geochemistry and paleontology. Micropaleontology 2003, 49, 41-59. [CrossRef]

29. Schneider-Mor, A.; Bowen, G.J. Coupled and decoupled responses of continental and marine organic-sedimentary systems through the Paleocene-Eocene thermal maximum, New Jersey margin, USA. Paleoceanography 2013, 28, 105-115. [CrossRef]

30. Cramer, B.S.; Aubry, M.P.; Miller, K.G.; Olsson, R.K.; Wright, J.D.; Kent, D.V. An exceptional chronologic, isotopic, and clay mineralogic record of the latest Paleocene thermal maximum, Bass River, NJ, ODP 174AX. Bull. Soc. Geol. France 1999, 170, 883-897.

31. Giusberti, L.; Rio, D.; Agnini, C.; Backman, J.; Fornaciari, E.; Tateo, F.; Oddone, M. Mode and tempo of the Paleocene-Eocene thermal maximum in an expanded section from the Venetian pre-Alps. Geol. Soc. Am. Bull. 2007, 119, 391-412. [CrossRef]

32. Kaiho, K.; Arinobu, T.; Ishiwatari, R.; Morgans, H.E.G.; Okada, H.; Takeda, N.; Tazaki, K.; Zhou, G.; Kajiwara, Y.; Matsumoto, R.; et al. Latest Paleocene benthic foraminiferal extinction and environmental changes at Tawanui, New Zealand. Paleoceanography 1996, 11, 447-465. [CrossRef]

33. Bolle, M.P.; Adatte, T. Palaeocene- early Eocene climatic evolution in the Tethyan realm: Clay mineral evidence. Clay Miner. 2001, 36, 249-261. [CrossRef]

34. van der Meulen, B.; Gingerich, P.D.; Lourens, L.J.; Meijerc, N.; van Broekhuizen, S.; van Ginneken, S.; Abels, H.A. Carbon isotope and mammal recovery from extreme greenhouse warming at the Paleocene-Eocene boundary in astronomically-calibrated fluvial strata, Bighorn Basin, Wyoming, USA. Earth Planet. Sci. Lett. 2020, 534, 116044. [CrossRef]

35. Kelly, D.C.; Zachos, J.C.; Bralower, T.J.; Schellenberg, S. Enhanced terrestrial weathering/runoff and surface ocean carbonate production during the recovery stages of the Paleocene-Eocene thermal maximum. Paleoceanography 2005, 20, PA1023. [CrossRef]

36. Crouch, E.M.; Dickens, G.R.; Brinkhuis, H.; Aubry, M.-P.; Hollis, C.J.; Rogers, K.M.; Visscher, H. The Apectodinium acme and terrestrial discharge during the Paleocene-Eocene thermal maximum: New palynological, geochemical and calcareous nannoplankton observations at Tawanui, New Zealand. Palaeogeogr. Palaeoclim. Palaeoecol. 2003, 194, 387-403. [CrossRef] 
37. Gawenda, P.; Winkler, W.; Schmitz, B.; Adatte, T. Climate and bioproductivity control on carbonate turbidite sedimentation (Paleocene to Earliest Eocene, Gulf of Biscay, Zumaia, Spain). J. Sediment. Res. 1991, 49, 1253-1261. [CrossRef]

38. Robert, C.; Chamley, H. Development of early Eocene warm climates, as inferred from clay mineral variations in oceanic sediments. Glob. Planet. Chang. 1991, 89, 315-331. [CrossRef]

39. Gavrilov, Y.O.; Golovanova, O.V.; Shchepetova, E.V.; Pokrovsky, B.G. Lithological and Geochemical Characteristics of the Paleocene/Eocene Sediments corresponding to the PETM Biospheric Event in the Eastern Crimea (Nasypnoe Section). Lithol. Miner. Resour. 2018, 53, 337-348. [CrossRef]

40. Do Campo, M.; Bauluz, B.; del Papa, C.; White, T.; Yuste, A.; Mayayo, M.J. Evidence of cyclic climatic changes recorded in clay mineral assemblages from a continental Paleocene-Eocene sequence, northwestern Argentina. Sediment. Geol. 2018, 368, 44-57. [CrossRef]

41. Chen, Z.; Ding, Z.; Yang, S.; Zhang, C.; Wang, X. Increased precipitation and weathering across the Paleocene-Eocene Thermal Maximum in central China. Geochem. Geophys. Geosyst. 2016, 87, 2286-2297. [CrossRef]

42. Pujalte, V.; Baceta, J.L.; Schmitz, B. A massive input of coarse-grained siliciclastics in the Pyrenean Basin during the PETM: The missing ingredient in a coeval abrupt change in hydrological regime. Clim. Past 2015, 11, 1653-1672. [CrossRef]

43. Bornemann, A.; Norris, R.D.; Lyman, J.A.; D’haenens, S.; Groeneveld, J.; Röhl, U.; Farley, K.A.; Speijer, R.P. Persistent environmental change after the Palaeocene-Eocene Thermal Maximum in the eastern North Atlantic. Earth Planet. Sci. Lett. 2014, 394, 70-81. [CrossRef]

44. Khozyem, H.; Adatte, T.; Spangenberg, J.E.; Tantawy, A.A.; Keller, G. Palaeoenvironmental and climatic changes during the Palaeocene-Eocene Thermal Maximum (PETM) at the Wadi Nukhul Section, Sinai, Egypt. J. Geol. Soc. Lond. 2013, 170, 2012-2046. [CrossRef]

45. Wieczorek, R.; Fantle, M.S.; Kump, L.R.; Ravizza, G. Geochemical evidence for volcanic activity prior to and enhanced terrestrial weathering during the Paleocene Eocene Thermal Maximum. Geochim. Cosmochim. Acta 2013, 119, 391-410. [CrossRef]

46. John, C.M.; Banerjee, N.R.; Longstaffe, F.J.; Sica, C.; Law, K.R.; Zachos, J.C. Clay assemblage and oxygen isotopic constraints on the weathering response to the Paleocene-Eocene thermal maximum, east coast of North America. Geology 2012, 9, 591-594. [CrossRef]

47. Handley, L.; O’Halloran, A.; Pearson, P.N.; Hawkins, E.; Nicholas, C.J.; Schouten, S.; McMillan, I.K.; Pancost, R.D. Changes in the hydrological cycle in tropical East Africa during the Paleocene-Eocene Thermal Maximum. Palaeogeogr. Palaeoclim. Palaeoecol. 2012, 329-330, 10-21. [CrossRef]

48. Kender, S.; Stephenson, M.H.; Riding, J.B.; Leng, M.J.; Knox, R.W.O.; Peck, V.L.; Kendrick, C.P.; Ellis, M.A.; Vane, C.H.; Jamieson, R. Marine and terrestrial environmental changes in NW Europe preceding carbon release at the Paleocene-Eocene transition. Earth Planet. Sci. Lett. 2012, 353-354, 108-120. [CrossRef]

49. Harding, I.C.; Charles, A.J.; Marshall, J.E.A.; Palike, H.; Roberts, A.P.; Wilson, P.A.; Jarvis, E.; Thorne, R.; Morris, E.; Moremon, R.; et al. Sea-level and salinity fluctuations during the Paleocene-Eocene thermal maximum in Arctic Spitsbergen. Earth Planet. Sci. Lett. 2011, 303, 97-107. [CrossRef]

50. Dypvik, H.; Riber, L.; Burca, F.; Ruther, D.; Jargvoll, D.; Nagy, J.; Jochmann, M. The Paleocene-Eocene thermal maximum (PETM) in Svalbard-Clay mineral and geochemical signals. Palaeogeogr. Palaeoclim. Palaeoecol. 2011, 302, 156-169. [CrossRef]

51. White, P.D.; Schiebout, J. Paleogene paleosols and changes in pedogenesis during the initial Eocene thermal maximum: Big Bend National Park, Texas, USA. Geol. Soc. Am. Bull. 2008, 120, 1347-1361. [CrossRef]

52. Clechenko, E.R.; Kelly, D.C.; Harrington, G.J.; Stiles, C.A. Terrestrial records of a regional weathering profile at the Paleocene-Eocene boundary in the Williston Basin of North Dakota. Geol. Soc. Am. Bull. 2007, 119, 428-442. [CrossRef]

53. Ernst, S.R.; Guasti, E.; Dupuis, C.; Speijer, R.P. Environmental perturbation in the southern Tethys across the Paleocene/Eocene boundary (Dababiya, Egypt): Foraminiferal and clay mineral records. Mar. Micropaleontol. 2006, 60, 89-111. [CrossRef]

54. Huggett, M.J.; Knox, R.W.O. Clay mineralogy of the Tertiary onshore and offshore strata of the British Isles. Clay Miner. 2006, 41, 5-46. [CrossRef]

55. Harrington, G.J.; Kemp, S.J.; Koch, P.L. Palaeocene-Eocene paratropical floral change in North America: Responses to climate change and plant immigration. J. Geol. Soc. 2004, 161, 173-184. [CrossRef] 
56. Knox, R.W.O.; Aubry, M.P.; Berggren, W.A.; Dupuis, C.; Ouda, K.; Magioncalda, R.; Soliman, M. The Qreiya section at Gebel Abu Had: Lithostratigraphy, clay mineralogy, geochemistry and biostratigraphy. Micropaleontology 2003, 49, 93-104. [CrossRef]

57. Schmitz, B.; Pujalte, V. Sea-level, humidity, and land-erosion records across the initial Eocene thermal maximum from a continental-marine transect in northern Spain. Geology 2003, 31, 689-692. [CrossRef]

58. Egger, H.; Homayoun, M.; Schnabel, W. Tectonic and climatic control of Paleogene sedimentation in the Rhenodanubian Flysch basin (Eastern Alps, Austria). Sediment. Geol. 2002, 152, 247-262. [CrossRef]

59. Schmitz, B.; Pujalte, V.; Nunez-Betelu, K. Climate and sea-level perturbations during the incipient Eocene thermal maximum: Evidence from siliciclastic units in the Basque Basin (Ermua, Zumaia and Trabakua Pass), northern Spain. Palaeogeogr. Palaeoclim. Palaeoecol. 2001, 165, 299-320. [CrossRef]

60. Gibson, T.G.; Bybell, L.M.; Mason, D.B. Stratigraphic and climatic implications of clay mineral changes around the Paleocene/Eocene boundary of the northeastern US margin. Sediment. Geol. 2000, 134, 65-92. [CrossRef]

61. Knox, R.W.O. Kaolinite influx within Paleocene/Eocene boundary stata of Western Europe (Extended abstract). Newsl. Stratigr. 1998, 36, 49-53. [CrossRef]

62. Robert, C.; Kennett, J.P. Antarctic Subtropical Humid Episode at the Paleocene-Eocene Boundary-Clay-Mineral Evidence. Geology 1994, 22, 211-214. [CrossRef]

63. Bergaya, F.; Lagaly, G. General Introduction. In Clays, Clay Minerals, and Clay Science, 2nd ed.; Bergaya, F., Lagaly, G., Eds.; Developments in Clay Science 5A; Elsevier: Amsterdam, The Netherlands, 2013; pp. 1-19.

64. Tomadin, L. Rappresentatività dei campioni e riproducibilità delle analisi di sedimenti argillosi nelle ricerche geologicje ed ambientali. Incontr. Sci. 2000, II, 1-8.

65. Schultz, L.G. Quantitative Interpretation of Mineralogical Composition from X-ray and Chemical Data for the PierreShale; USGS Professional Paper 391-C; United States Government Printing Office: Washington, WA, USA, 1964; pp. 1-31.

66. Biscaye, P.E. Mineralogy and Sedimentation of Recent Deep-Sea Clay in the Atlantic Ocean and Adjacent Seas and Oceans. Geol. Soc. Am. Bull. 1965, 76, 803-832. [CrossRef]

67. Guggenheim, S.; Martin, R.T. Definition of clay and clay mineral: Joint report of the AIPEA nomenclature and CMS nomenclature committees. Clays Clay Miner. 1995, 43, 255-256. [CrossRef]

68. Millot, G. Geology of Clays; Springer: Wien, Austria, 1970; p. 429.

69. Chamely, H. Clay Sedimentology; Springer: Berlin/Heidelberg, Germany, 1989; p. 623.

70. Schroeder, P.A. Clays in the Critical Zone; Cambridge University Press: Cambridge, UK, 1989; p. 246.

71. Moore, D.M.; Reynolds, R.C. X-ray Diffraction and the Identification and Analysis of Clay Minerals, 2nd ed.; Oxford University Press: New York, NY, USA, 1997; p. 376.

72. Wlson, M.J. Rock-Forming Minerals, Volume 3C: Sheet Silicate; The Geological Society: London, UK, 2013.

73. Godet, A.; Bodin, S.; Adatte, T.; Follmi, K. Platform-induced clay-mineral fractionation along a northern Tethyan basin-platform transect: Implications for the interpretation of Early Cretaceous climate change (Late Hauterivian-Early Aptian). Cretac. Res. 2008, 29, 830-847. [CrossRef]

74. Thiry, M.; Dupuis, C. Use of clay minerals for paleoclimatic reconstructions: Limits of the method with special reference to the Paleocene-lower Eocene interval. GFF 2000, 122, 166-167. [CrossRef]

75. Fagel, N. Clay Minerals, Deep Circulation and Climate. In Developments in Marine Geology; Hillaire-Marcel, C., De Vernal, A., Eds.; Elsevier: Amsterdam, The Netherlands, 2007; Volume 1, pp. 139-184.

76. Calvo, J.P.; Pozo, M. Geology of magnesian clays in sedimentary and non-sedimentary environments. In Magnesian Clays; Pozo, M., Galan, E., Eds.; AIPEA Educational Series; Digilabs: Bari, Italy, 2015; Volume 2, pp. 123-173.

77. Cavalcante, F.; Belviso, C.; Bentivenga, M.; Fiore, S.; Prosser, G. Occurrence of palygorskite and sepiolite in upper Paleocene-middle Eocene marine deep sediments of the Lagonegro Basin (Southern Apennines-Italy): Paleoenvironmental and provenance inferences. Sediment. Geol. 2011, 233, 42-52. [CrossRef]

78. Dinelli, E.; Tateo, F.; Summa, V. Geochemical and mineralogical proxies for grain size in mudstones and siltstones from the Pleistocene and Holocene of the Po River alluvial plain, Italy. In Sedimentary Provenance and Petrogenesis: Perspectives from Petrography and Geochemistry; Arribas, J., Critelli, S., Johnsson, M.J., Eds.; Geological Society of America Special Paper; Geological Society of America: Boulder, CO, USA, 2007; Volume 420, pp. 25-36. 
79. von Eynatten, H.; Tolosana-Delgado, R.; Karius, V.; Bachmann, K.; Caracciolo, L. Sediment generation in humid Mediterranean setting: Grain-size and source-rock control on sediment geochemistry and mineralogy (Sila Massif, Calabria). Sediment. Geol. 2016, 336, 68-80. [CrossRef]

80. Eberl, D.D.; Smith, D.B. Mineralogy of soils from two continental-scale transects across the United States and Canada and its relation to soil geochemistry and climate. Appl. Geochem. 2009, 24, 1394-1404. [CrossRef]

81. Guyot, J.L.; Jouanneau, J.M.; Soares, L.; Boaventura, G.R.; Maillet, N.; Lagane, C. Clay mineral composition of river sediments in the Amazon Basin. Catena 2007, 71, 340-356. [CrossRef]

82. Martinez-Ruiz, F.; Kastner, M.; Gallego-Torres, D.; Rodrigo-Gamiz, M.; Nieto-Moreno, V.; Ortega-Huertas, M. Paleoclimate and paleoceanography over the past 20,000 yr in the Mediterranean Sea Basins as indicated by sediment elemental proxies. Quat. Sci. Rev. 2015, 107, 25-46. [CrossRef]

83. Tamburini, F.; Adatte, T.; Follmi, K.; Bernasconi, S.M.; Steinmann, P. Investigating the history of East Asian monsoon and climate during the last glacial-interglacial period (0-140000 years): Mineralogy and geochemistry of ODPSites 1143 and 1144, South China Sea. Mar. Geol. 2003, 201, 147-168. [CrossRef]

84. Chen, Q.; Zhifei, Z.; Kissel, C. Clay mineralogical and geochemical proxies of the East Asian summer monsoon evolution in the South China Sea during Late Quaternary. Sci. Rep. 2017, 7, 42083. [CrossRef] [PubMed]

85. Clift, P.D.; Hodges, K.; Heslop, D.; Hannigan, R.; Hoang, L.V.; Calves, G. Correlation of Himalayan exhumation rates and Asian monsoon intensity. Nat. Geosci. 2008, 1, 875-880. [CrossRef]

Publisher's Note: MDPI stays neutral with regard to jurisdictional claims in published maps and institutional affiliations.

(C) 2020 by the author. Licensee MDPI, Basel, Switzerland. This article is an open access article distributed under the terms and conditions of the Creative Commons Attribution (CC BY) license (http://creativecommons.org/licenses/by/4.0/). 